UDC 579.61

\title{
Identification and characterization of potential membrane-bound molecular drug targets of methicillin-resistant Staphylococcus aureus using in silico approaches
}

\author{
A. Yu. Pernatii ${ }^{1}$, G. P. Volynets ${ }^{1}$, M. V. Protopopov ${ }^{1}$, A. O. Prykhod'ko ${ }^{1,2}$, V. M. Sapelkin ${ }^{1}$, \\ L. V. Pletnova ${ }^{1}$, V. I. Matiushok ${ }^{1,2}$, V. G. Bdzhola ${ }^{1}$, S. M. Yarmoluk ${ }^{1}$ \\ ${ }^{1}$ Institute of Molecular Biology and Genetics, NAS of Ukraine \\ 150, Akademika Zabolotnoho Str., Kyiv, Ukraine, 03143 \\ ${ }^{2}$ LLC "Scientific and service firm "Otava" \\ 150, Akademika Zabolotnoho Str., Kyiv, Ukraine, 03143 \\ sergiy@yarmoluk.org.ua.
}

\begin{abstract}
Aim. To identify novel putative drug targets of methicillin-resistant S. aureus (MRSA) through subtractive proteome analysis. Methods. Identification of non-homologous proteins in the human proteome, search of MRSA essential genes and evaluation of drug target novelty were performed using a protein BLAST server. Unique metabolic pathways identification was carried out using data and tools from KEGG (Kyoto Encyclopedia of Genes and Genomes). Prediction of sub-cellular proteins localization was performed using combination of PSORT v. 3.0.2, CELLO v. 2.5, iLoc-Gpos, and Pred-Lipo tools. Homology modeling was performed using SWISS-MODEL, Phyre2, I-TASSER web-servers and the MODELLER software. Results. Proteomes of six annotated methicillin-resistant strains : MRSA ATCC BAA-1680, H-EMRSA-15, LA MRSA ST398, MRSA 252, MRSA ST772, UTSW MRSA 55 were initially analyzed. The proteome analysis of the MRSA strains in several consequent steps allowed to identify two molecular targets: diadenylate cyclase and D-alanyl-lipoteichoic acid biosynthesis (DltB) protein which meet the requirements of being essential, membrane-bound, non-homologous to human proteome, involved in unique metabolic pathways and new in terms of not having approved drugs. Using the homology modeling approach, we have built three-dimensional structures of these proteins and predicted their ligand-binding sites. Conclusions. We used classical bioinformatics approaches to identify two molecular targets of MRSA :diadenylate cyclase and DltB which can be used for further rational drug design in order to find novel therapeutic agents for treatment of multidrug resistant staphylococcal infection.
\end{abstract}

Keyword s: molecular drug targets; methicillin-resistant Staphylococcus aureus; MRSA; subtractive proteome analysis.

2019 A. Yu. Pernatii et al:; Published by the Institute of Molecular Biology and Genetics, NAS of Ukraine on behalf of Biopolymers and Cell. This is an Open Access article distributed under the terms of the Creative Commons Attribution License (http://creativecommons.org/licenses/by/4.0/), which permits unrestricted reuse, distribution, and reproduction in any medium, provided the original work is properly cited 


\section{Introduction}

Staphylococcus aureus is the leading cause of hospital-acquired infections, which range from mild skin and soft tissue infections to more severe diseases, such as endocarditis, bacteremia, sepsis, and osteomyelitis [1]. S. aureus belongs to ESKAPE pathogens that are difficult to treat due to increasing multidrug resistance. Penicillin was effective against staphylococcal infections until strains evolved the mechanism to hydrolyse the $\beta$-lactam ring of antibiotic. Staphylococcal resistance to penicillin is mediated by penicillinase. Today, in clinical practice methicillin - chemically modified penicillin which cannot be hydrolysed by penicillinase - is widely used for treatment of staphylococcal infections. At present, methicillin-resistant $S$. aureus (MRSA) is one of the most feared strains of $S$. aureus which have become resistant to most of $\beta$-lactam antibiotics. For this reason, vancomycin is commonly used to combat MRSA. Recently, the vancomycin-resistant $S$. aureus strains have also emerged. Noteworthy, none drug to date has shown superiority to vancomycin in the treatment of MRSA infections with the possible exception of linezolid in hospital-acquired pneumonia [2]. Therefore, the development of novel antibiotics for the treatment of staphylococcal infections is of great interest. The ability of bacteria to rapidly acquire drug resistance requires the selection of novel proper molecular targets. Today, a number of proteins are considered as promising drug targets for the development of antibiotics to treat staphylococcal infections. After extensive review of the literature for the last three years, the following proteins were considered as potential therapeutic drug targets for the development of antistaphylococcal agents: bacterial enoyl reductase (FabI) [3,4], transglycosylase (TGase) [5,6], sortase A [7-13], diapophytoene desaturase (CrtN) [14-17], type II topoisomerase [18-21], topoisomerase IV [22-27], filamentous temperature-sensitive protein Z (FtsZ) [28-30], UDP-N-acetylenolpyruvylglucosamine reductase (MurB) [31], lipoteichoic acid synthase (LtaS) [32], biotin protein ligase [33,34], peptide deformylase [35], Ser/Thr protein kinase STK1 [36], pentaerythritol tetranintrate reductase [37], peptide deformylase (PDF) [38, 39], NorA efflux pump [40-46], poly-beta-1,6$\mathrm{N}$-acetyl-D-glucosamine synthase (IcaA) [47], dihydrofolate reductase (DHFR) [48], phenylalanine tRNA synthetase (PheRS) [49],4-dihydroxy-2-naphthoate prenyltransferase (MenA) [50], SecA ATPase [51], biotin protein ligase (BPL) [52], UDP-MurNAc-pentapeptide (MurF), uridine monophospate kinase (UMPK) [53], N-Acetylneuraminate lyase [54], 6-Hydroxymethyl-7,8-dihydropterin pyrophosphokinase (HPPK) [55, 56], caseinolytic protease ClpP [57], multidrug efflux pump LmrS [58], collagen (Cn)-binding protein Can [59], pantothenate kinase [60], undecaprenyl diphosphate synthase $[61,62]$ and undecaprenyl diphosphate phosphatase [61, 63], MurE [64], bacterial pathway for fatty acid biosynthesis, FASII [65], pyruvate kinase [66, 67], nitric oxide synthase [68], eukaryotic-like Ser/Thr phosphatase Stp1 [69], tyrosyl-tRNA synthetase (TyrRSs) [70], heptaprenyl diphosphate synthase (HepPPS) [71], $\beta$-Ketoacyl-ACP synthases (KAS) [72], RNA polymerase [73], UDP-GlcNAc 2-epimerase (MnaA) [74], 


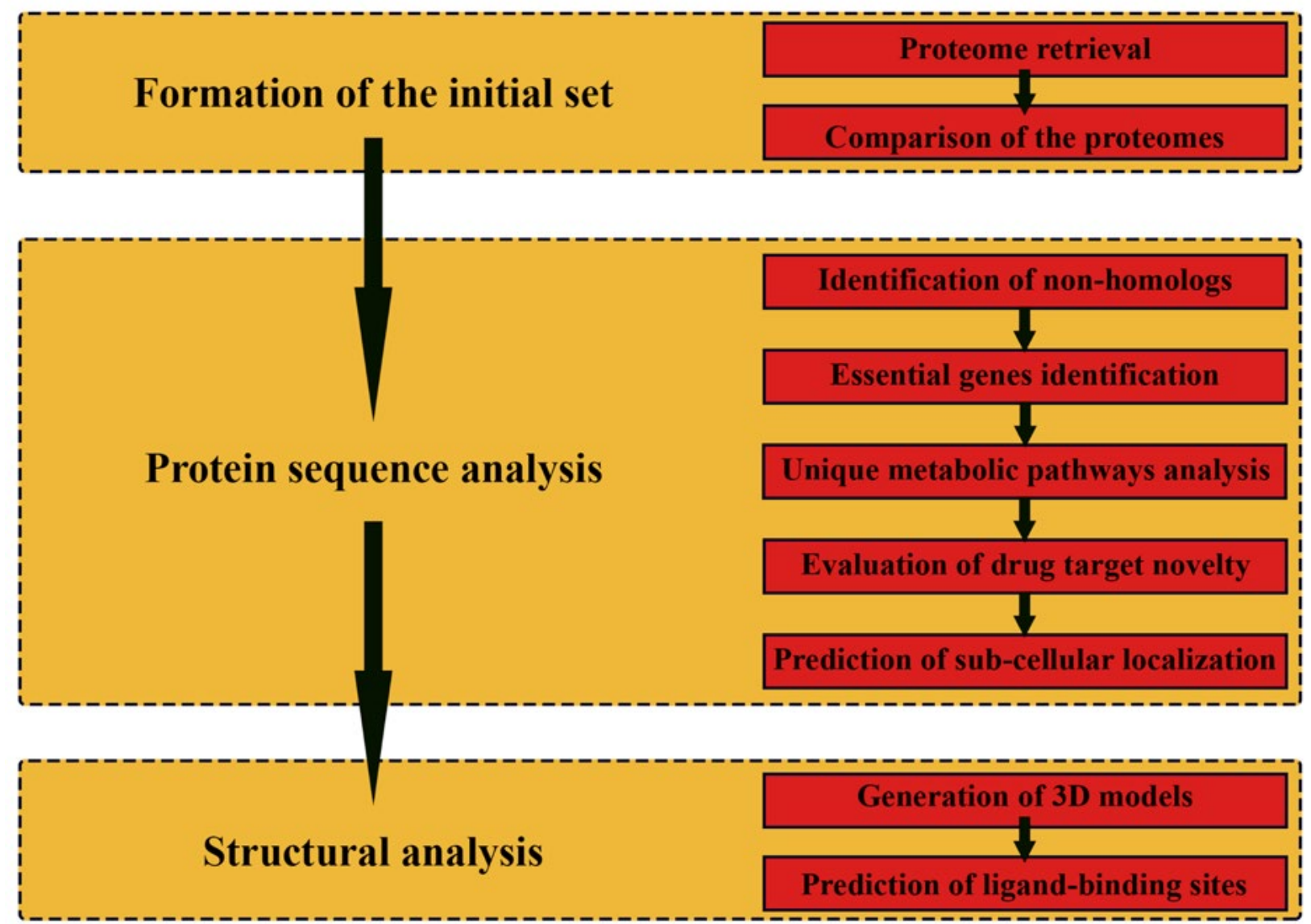

Fig. 1. The workflow of the analysis

ATPase [75], mevalonate diphosphate decarboxylase (MDD) [76], glycosyltransferase [77].

In spite of large amount of proposed molecular targets, there are currently only nine investigational antibiotics against $S$. aureus, including MRSA, undergoing clinical trials but targeting only four proteins, such as DNA gyrase, topoisomerase IV, enoyl-acyl-carrier (ACP) reductase (FabI) and $\mathrm{P}$ site at the 50S ribosome subunit of bacteria [78].

Due to fast growth of resistant strains, the identification of unique drug targets amongst the resistant pathogens is very important. A number of methods are currently available to identify potential drug targets. Among them, bioinformatics approaches are the most fast and cost-effective. For example, subtractive genome analysis has been already used to identify putative molecular targets for different pathogenic strains of Staphylococcus aureus, such as Staphylococcus aureus subsp. aureus MW2 (CA-MRSA) [79], Staphylococcus aureus N315 [80], Staphylococcus aureus ST398, S. aureus 252 [81, 82], vancomycin-resistant Staphylococcus aureus [83]. The aim of this 
study is the identification of novel membranebound putative molecular targets common for all already sequenced methicillin-resistant strains of Staphylococcus aureus.

\section{Methods}

The procedure of potential drug targets identification in our work included formation of the initial set, protein sequence analysis, and structural analysis. The workflow is presented in Figure 1.

\section{Proteome retrieval of MRSA strains}

Complete proteomes of six methicillin-resistant strains of $S$. aureus were downloaded in FASTA format from the NCBI Protein database that contains sequences from GenBank, TPA, RefSeq, PRF, PIR, SwissProt, and PDB on April 10, 2018. Besides the sequences themselves, NCBI also provided general information about the targeted strains genome annotation data.

\section{Comparison of the proteomes}

In order to form the initial set of proteins for the analysis, [the] NCBI accession numbers (ACs) of the proteins from different strains were compared manually. Only the proteins with common ACs were included into the initial set, the others were not considered, because they were suggested to have some differences between the strains which might have an impact on the potential drug effectiveness.

\section{Identification of non-homologous proteins to the human proteome}

The representative set was subjected to Protein BLAST against human proteome with the expectation-value cutoff of $10^{-3}$. BLOSUM62 was chosen as the scoring matrix for the BLASTP algorithm, the non-redundant protein sequences were taken as the search set database. As a result, we have obtained homologous sequences, with significant similarity to human proteome, and non-homologous sequences, for which no hits with significant similarity were found. The proteins with homology to the human proteome were excluded from the set, thus were not taken into account during further analysis.

\section{MRSA essential genes identification}

The set of non-homologous proteins was further subjected for alignment against the Database of Essential Genes (DEG) [84, 85]. The current version of this database contains essential genes of two $S$. aureus strains NCTC 8325 and N315. The sequences were filtered using following settings: BLASTP as the algorithm, BLOSUM62 as the substitution matrix, expectation value cutoff equals to $10^{-5}$, minimal score equals to 100 . The proteins which met the E-value cutoff and minimal score were considered to be essential for pathogen survival and propagation.

\section{Unique metabolic pathways identifica- tion}

Using the data and tools from KEGG (Kyoto Encyclopedia of Genes and Genomes), the metabolic pathway analysis was carried out to determine unique metabolic pathways of the pathogen. KEGG is an integrated database that contains systems, genomic, chemical and health information allowing biological interpretation of genome sequences and other throughput data $[86,87]$. All the essential non- 
homologous proteins were analyzed by KEGG Automatic Annotation Server (KAAS). It provides functional annotation of genes or proteins by BLAST or GHOST comparisons against manually curated KEGG databases [88]. In this study we used BLASTP as the algorithm for such comparison. As a result we obtained a $\mathrm{KO}$ assignment list, on the basis of which the manual selection of proteins involved in unique metabolic pathways was performed.

\section{Evaluation of drug target novelty}

To separate already-known drug targets from novel ones, protein BLAST against DrugBank database was performed. The latest version of DrugBank (5.1.0) contains 11143 drug entries, including 2555 approved small molecule drugs, 965 approved biotech drugs, 121 nutraceuticals, and over 5145 experimental drugs. 5121 non-redundant protein sequences are linked to these entries [89]. This allowed us to exclude the proteins that have proper ligands from further analysis.

\section{Prediction of sub-cellular localization of proteins}

The important question to be addressed when choosing a target for further drug development is the localization of that particular target inside a cell. Compartment localization determines the methods for protein extraction and purification, which makes upcoming investigational steps easier or harder. In order to predict the sub-cellular localization of druggable non-homologous essential proteins a combination of tools such as PSORT v. 3.0.2 [90], CELLO v. 2.5 [91], iLoc-Gpos [92], and Pred-Lipo [93] was used. The localization was assigned to a protein only in the case when all four tools obtained the same results.

\section{Homology modeling of proteins}

Three dimensional models for the resulting protein set were generated on the basis of homology modeling by web-servers SWISSMODEL (https://swissmodel.expasy.org/interactive) [94-99], Phyre2 (http://www.sbg.bio. ic.ac.uk/phyre $2 / \mathrm{html} /$ page.cgi?id=index $[100$, 101] and I-TASSER (https://zhanglab.ccmb. med.umich.edu/I-TASSER/) [102-105] with default parameters and Modeller 9.17 using basic modeling mode (https://salilab.org/modeller/tutorial/basic.html) [106-109]. The models were minimized with GROMACS software [110-112] using steepest descent algorithm (1000 steps of minimization). The accuracy of this modeling was validated using MolProbity web-server [113]. The structures for template proteins were retrieved from the Protein Data Bank. In cases, when the performing of homology modeling was impossible, the 3D-structure was built ab initio using I-TASSER web-server. The modeled structures for the target proteins were analyzed with ProBiS Tools [114] in order to predict the binding sites of the proteins.

\section{Results and Discussion}

The objective of this study was to identify the novel putative drug targets of methicillin-resistant $S$. aureus (MRSA) through subtractive genomic analysis. The combination of subtractive genomic analysis and comparative genomics/proteomics is a powerful method for identification of unique sequences with certain metabolic functions.

Noteworthy, not all methicillin-resistant strains of $S$. aureus have either their genomes 
sequenced completely or proteomes annotated. Therefore, in this study we have compared annotated proteomes of already sequenced methicillin-resistant strains, namely MRSA ATCC BAA-1680 [115], H-EMRSA-15 [116], LA MRSA ST398 [117], MRSA 252 [118], ST772 MRSA [119], and UTSW MRSA 55 [120], in order to identify common sequences.

The total number of proteins for each strain, which have been retrieved from NCBI Protein database, is indicated in Table 1.

Following the procedure indicated in Fig. 1, we analyzed the proteome of MRSA in several steps; the results are given in Table 2.

The comparative analysis of protein accession numbers showed that only 326 sequences

Table 1. Total number of proteins corresponding to strains during analysis

\begin{tabular}{l|c|c}
\hline \multicolumn{1}{c|}{ Strain } & $\begin{array}{c}\text { Isolate (if } \\
\text { any reference } \\
\text { available) }\end{array}$ & $\begin{array}{c}\text { Total number } \\
\text { of proteins }\end{array}$ \\
\hline MRSA ATCC BAA-1680 & $25 \mathrm{~b}$ & 2874 \\
\hline & $26 \mathrm{~b}$ & 2872 \\
\hline & $27 \mathrm{~b}$ & 2873 \\
\hline & $29 \mathrm{~b}$ & 2873 \\
\hline H-EMRSA-15 & $31 \mathrm{~b}$ & 2873 \\
\hline LA MRSA ST398 & - & 2775 \\
\hline MRSA 252 & - & 2767 \\
\hline MRSA ST772 & - & 2819 \\
\hline UTSW MRSA 55 & - & 2806 \\
\hline
\end{tabular}

Table 2. Subtractive analysis results for MRSA

\begin{tabular}{l|c}
\hline \multicolumn{1}{c|}{ Analytical step of the analysis } & $\begin{array}{c}\text { Total number } \\
\text { of proteins }\end{array}$ \\
\hline Representative set of MRSA proteins & 326 \\
\hline Non-homologous proteins & 172 \\
\hline Essential proteins & 45 \\
\hline Proteins after KEGG analysis & 28 \\
\hline Potentially novel drug targets & 22 \\
\hline Membrane-bound proteins & 2 \\
\hline
\end{tabular}

are common for the abovementioned MRSA strains, the corresponding accession numbers and definitions are given in Supplementary table 1 . The resulting set does not exhaust the pool of common proteins due to possible inconsistencies between the accession numbers originated from different sources but can still be considered adequate for the search of common molecular targets.

The existence of homologous proteins between bacteria and human is believed to have emerged in course of evolution [121-123]. A number of studies assume a "similarity hypothesis" that states homology as an evolutionary adaptation of pathogens to prevent being recognized by host's immune system [124, 125]. The selection of particular homologous pairs as potential drug targets against MRSA might lead to cross-reactivity in human hosts. That is the reason why in the next step the sequences from the representative set were subjected to Protein BLAST against the whole human genome with a threshold E-value of $10^{-3}$. The proteins with significant similarity were excluded from further analysis to prevent crossreactions between human and pathogen during pharmaceutical treatment. This step reduced the number of sequences in the representative set to 172 .

We determined the essentiality of the nonhomologous proteins of methicillin-resistant $S$. aureus based on bioinformatics prediction through homology search in DEG against known essential genes identified by an antisense RNA technique of two $S$. aureus strains, NCTC 8325 and N315. This approach has a crucial useful feature. Essential genes of an organism constitute the minimal set of genes required for a living cell in given growth con- 


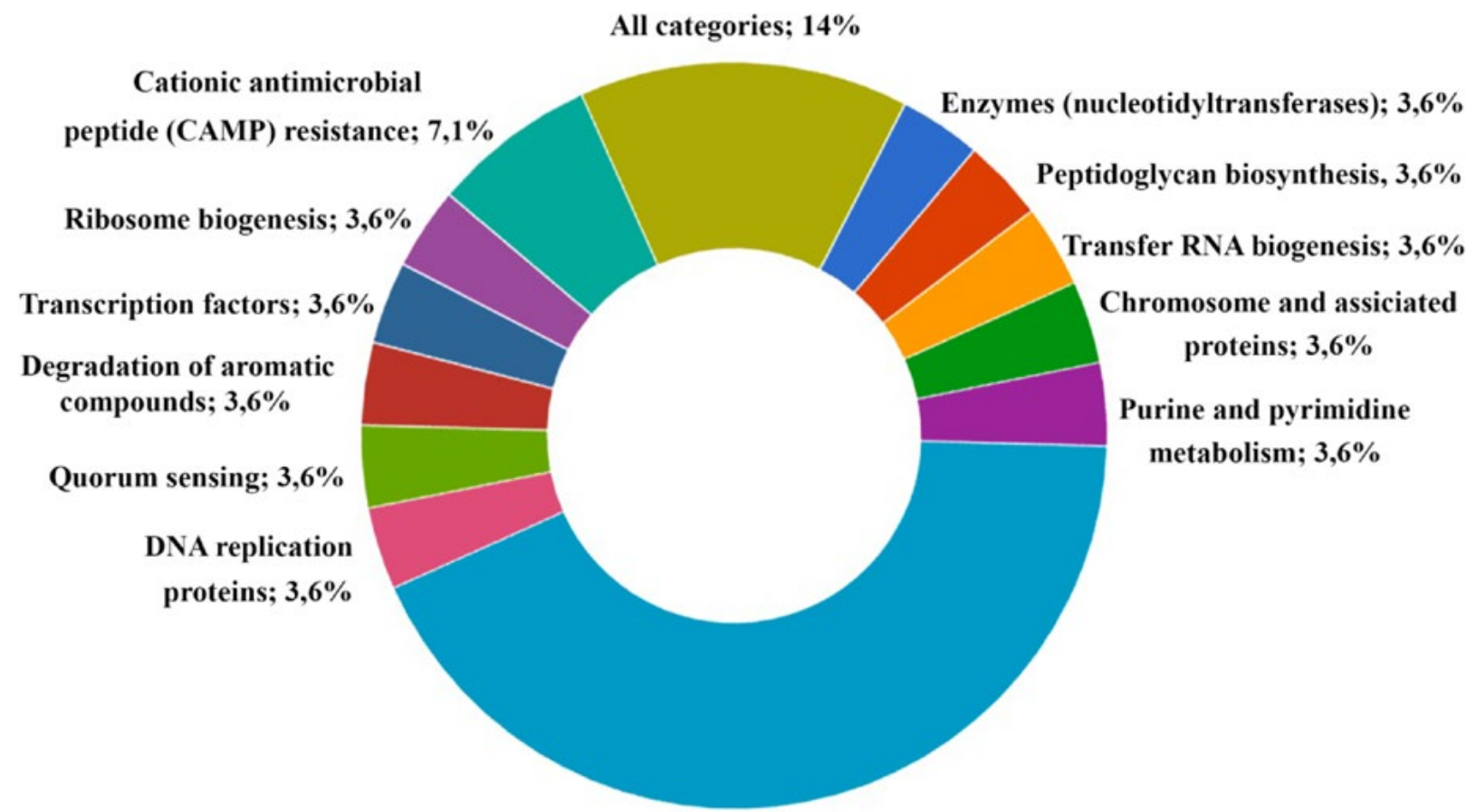

Ribosome; $\mathbf{4 3 \%}$

Fig. 2. Orthology groups of analyzed proteins

ditions. Thus, the proteins, coded by corresponding essential genes, have higher druggability potential. Protein BLAST against DEG revealed that 45 sequences from our set had homologs with sequences from DEG. Noteworthy, a certain distribution of the amount of homologs between our set and DEG was observed, e.g., one sequence had 4 homologs in DEG, 11 sequences had 2 homologs each, and the rest of the set had just one corresponding homolog. Supplementary table 2 contains the results obtained during performing this step.

KAAS was used to determine whether the resulted outcome from the DEG step was involved in essential metabolic pathways. More importantly, the analysis with KAAS enabled us to exclude non-homologous essential proteins potentially having the enzymatic activity for reactions of human metabolism or a similar function regarding genetic information processing or signaling and cellular processes. The comparison was carried out between $S$. aureus and human metabolic networks and revealed that 28 sequences out of $45 \mathrm{had}$ a significant similarity to $S$. aureus enzymes and at the same time had none to human. After the manual revision of $\mathrm{KO}$ numbers all sequences were classified according to their orthology groups, the distribution of the analyzed proteins throughout KEGG metabolic networks is represented in Figure 2.

Since the objective of our study was to identify the novel putative drug targets we 
have evaluated the druggability of the predicted in previous steps protein set by Protein BLAST analysis against DrugBank database (DBD) v. 5.1.0. DrugBank is a freely available web resource containing detailed drug, drugtarget, drug action and drug interaction information about FDA-approved drugs and experimental drugs going through the FDA approval process. The results, as shown in Table 3, indicate that 6 proteins out of the analyzed set interact with certain drugs.

Further, the sub-cellular localization of each protein has been predicted using PSORT v. 3.0.2, CELLO v. 2.5, iLoc-Gpos, and PredLipo. The results are presented in Supplementary table 3 . Together, the obtained results provide us with a set of novel putative drug targets of MRSA, including two membrane-bound proteins, namely TIGR00159 family protein (diadenylate cyclase) and WP_000613541.1 (D-alanyl-lipoteichoic acid biosynthesis protein DltB).

Diadenylate cyclase is an essential bacterial enzyme which utilizes two molecules of adenosine triphosphate (ATP) for the synthesis of the important second messenger - cyclic diadenylate monophosphate (c-di-AMP) which has been shown to regulate such processes as virulence, cell wall formation, cell size, ion transport, etc. Therefore, diadenylate cyclase is a potential target for the development of novel antibiotics. But only a small amount of low-molecular inhibitors for bacterial diadenylate cyclase has been reported in scientific literature so far. Recently, it was shown that several polyphenols inhibit Bacillus subtilis diadenylate cyclase [126]. Also, it was found that suramin, known antiparasitic drug is a potent inhibitor of diadenylate cyclase [127]. For the best of our knowledge, none small molecular inhibitor for $S$. aureus diadenylate cyclase has been reported.

DltB is a multi-membrane-spanning protein required for D-alanylation of teichoic acids which is important for the cell wall synthesis. Recently, Pasquina et al. [128] using the synthetic lethal approach have identified one compound that inhibits DltB $S$. aureus. It has been found that this inhibitor sensitizes $S$. aureus to several antibiotics and is lethal in combination with a wall teichoic acid inhibitor. Therefore, DltB can be considered as an important antibiotic target as well.

We have generated 3D models for diadenylate cyclase and D-alanyl-lipoteichoic acid biosynthesis protein DltB of $S$. aureus, which can be used for

further structure-based drug design. In order to identify template proteins for homology modeling of diadenylate cyclase and DltB

Table 3. The proteins which interact with the drugs accordingly to DrugBank data

\begin{tabular}{l|l|l}
\hline \multicolumn{1}{c|}{ NCBI Accession Number } & \multicolumn{1}{c}{ The drug } & \multicolumn{1}{c}{ Drug group } \\
\hline WP_000290472.1 & Troleandomycin & Approved \\
\hline WP_001123276.1 & 2-Oxo-3-Pentenoic Acid & Experimental \\
\hline WP_001274017.1 & 2-methylthio-N6-isopentenyl-adenosine-5'-monophosphate & Experimental \\
\hline WP_001549197.1 & N-Formylmethionine & Experimental \\
\hline WP_000692521.1 & Flavin mononucleotide & Approved, investigational \\
\hline WP_000562498.1 & Cladribine, Gallium nitrate & Approved, investigational \\
\hline
\end{tabular}


protein we have performed alignment of these sequences against Protein Data Bank (PDB) proteins using BLAST. It has been revealed that the most homologous protein for diadenylate cyclase $S$. aureus is diadenylate cyclase Listeria monocytogenes (PDB accession code: 4RV7) [129]. We have built four homology models of diadenylate cyclase of $S$. aureus based on crystal structure of diadenylate cyclase L. monocytogenes using web-servers Swiss-Model, Phyre2, I-TASSER and Modeller software tool. These homology models have been validated with MolProbity web-server. The MolProbity score combines the clashscore, rotamer and Ramachandran evaluations. The value of MolProbity score for [the] SwissModel homology model is 1.66 , for Phyre2 homology model -2.42 , for I-TASSER homology model -3.85 , for Modeller homology model -3.49 . Therefore, according to the obtained results, the homology model which was generated by Swiss-Model server, possesses the best value of MolProbity score and has been taken for further analysis. This homology model was minimized with GROMACS software using steepest descent algorithm (1000 steps). After minimization the MolProbity score was slightly improved (score value is 1.38 ).

The superposition of homology model of diadenylate cyclase of $S$. aureus (red colour) with crystal structure of diadenylate cyclase L. monocytogenes (blue colour) is represented in Figure 3a. RMSD value of diadenylate cyclase of $S$. aureus with template structure is 0.754493. An ATP molecule was chosen as a ligand for modeling. The resulted superimposed structures were further analyzed to locate the binding site residues of modeled diadenylate cyclase beyond the $7 \AA$ radius of the ligand (Figure $3 \mathrm{~b}$ ). The superposition of active sites of homology model (carbon atoms are labeled by green colour) and template structure (carbon atoms are labeled by white colour)
$A$

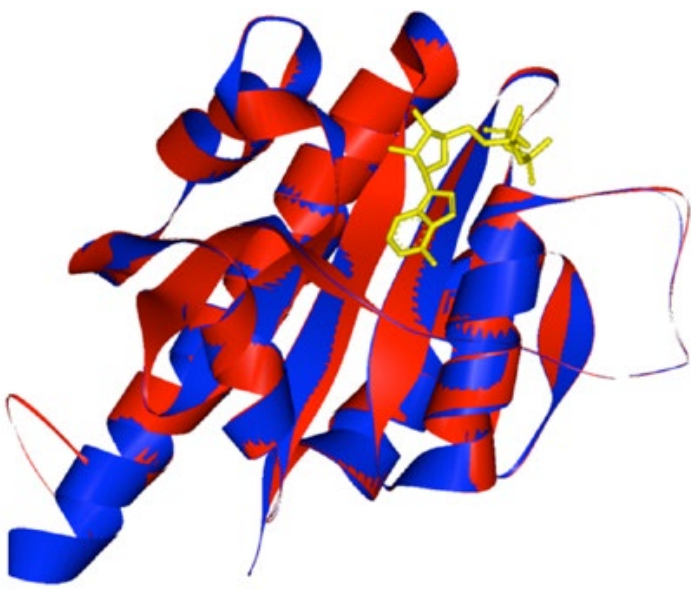

$B$

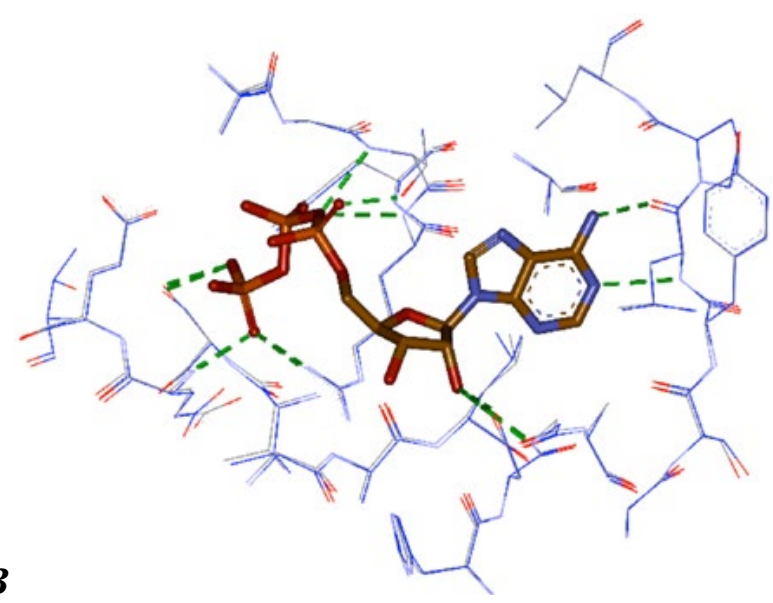

Fig. 3. The superposition of homology model of diadenylate cyclase $S$. aureus (red colour) with crystal structure of diadenylate cyclase L. monocytogenes (blue colour) (A) and superposition of active sites of homology model (carbon atoms are labeled by green colour) and template structure (carbon atoms are labeled by white colour) (B). The ligand is an ATP molecule. 
demonstrates that the structures of investigated enzymes are very similar. RMSD value of amino acid residues in the active sites of these enzymes is 0.885616 .

Using BLAST we have not identified any homologous protein for DltB, therefore the $3 \mathrm{D}$ model should to be generated only ab initio. We have built the model of DltB protein $S$. aureus using I-TASSER web-server. Confidence score (C-score) for the best model is -1.29. C-score is a confidence score for estimating the quality of predicted models by I-TASSER. It is calculated based on the significance of threading template alignments and

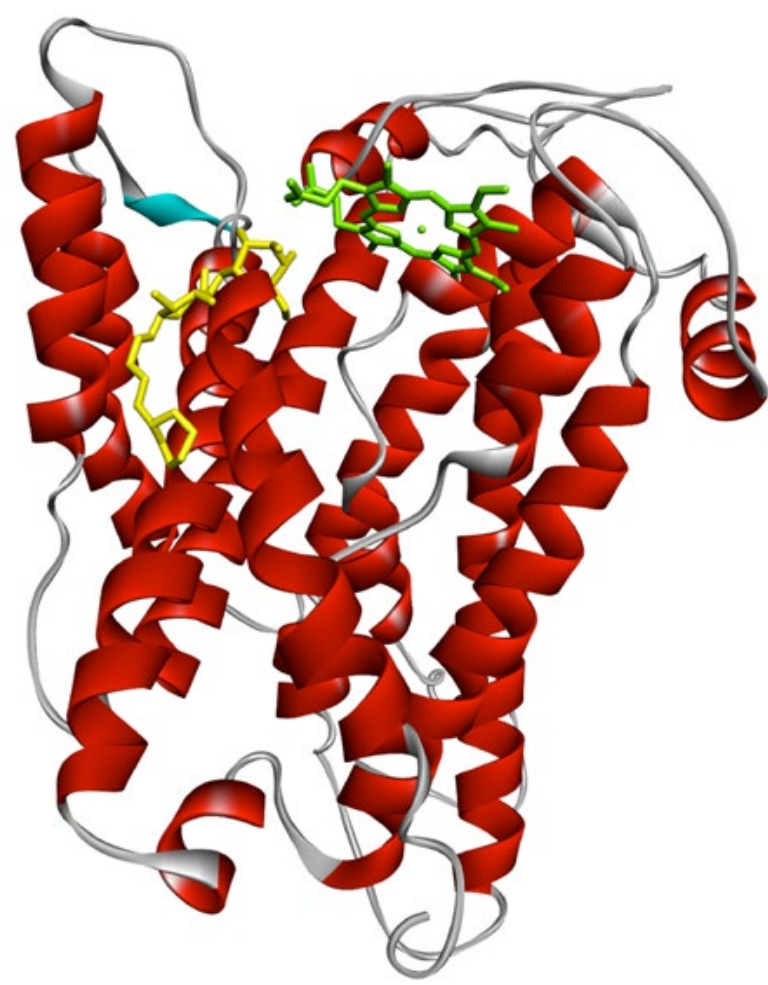

Fig. 4. The homology model of D-alanyl-lipoteichoic acid biosynthesis protein DltB S. aureus, obtained with I-TASSER server. The ligands (green heme and yellow CYMAL-4) indicate binding sites for small-molecular compounds. the convergence parameters of the structure assembly simulations. C-score varies typically from -5 to 2 . The MolProbity score for this homology model is 3.63 .

We tried to optimize I-TASSER homology model with GROMACS using different force fields but there were some problems with atom types. Therefore, we have built the homology model of DltB protein $S$. aureus by SwissModel server using as a template 3D model generated with I-TASSER server. This homology model was minimized with GROMACS using steepest descent algorithm (1000 steps). After minimization, the MolProbity score was significantly improved in comparison with the input model. MolProbity score of optimized model is 2.07 .

Also, we used ProBis tool to identify the binding sites of modeled DltB protein. Two potential binding sites, which can bind small molecules, have been predicted (see Figure 4). The binding pocket 1 (around green colored heme) is formed by amino acid residues Arg374, Asn377, Asn285, Lys284, Tyr33, Asn34, Val37, Gly35, Thr38, Ile208, Phe46, Ala204, Met41, Lys203, Glu199, Arg198. Pocket 2 (around yellow labeled CYMAL-4) is formed by amino acid residues Met97, Ala382, Phe379, Gly378, Asn377, Gln376, Trp375, Lys108, Arg374.

\section{Conclusion}

In this study we used classical bioinformatics approaches to estimate whether there are potential drug targets among methicillin-resistant Staphylococcus aureus proteins. Using subtractive genomic analysis we have identified two molecular targets of MRSA - diadenylate cyclase and D-alanyl-lipoteichoic acid biosyn- 
thesis protein which can be used for further rational drug design in order to identify novel therapeutic agents for the treatment of multidrug resistant staphylococcal infection.

\section{REFERENCES}

1. Jenkins A, An Diep B, Mai TT, Vo NH, Warrener P, Suzich J, Kendall Stover C, Sellman BR. Differential expression and roles of Staphylococcus aureus virulence determinants during colonization and disease. MBio. 2015; 6(1): e02272-14.

2. Holmes NE, Tong SYC, Davis JS, Hal SJV. Treatment of methicillin-resistant staphylococcus aureus: Vancomycin and beyond. Semin Respir Crit Care Med. 2015; 36(1): 17-30.

3. Kwon J, Mistry T, Ren J, Johnson ME, Mehboob S. A novel series of enoyl reductase inhibitors targeting the ESKAPE pathogens, Staphylococcus aureus and Acinetobacter baumannii. Bioorganic Med Chem. 2018; 26(1): 65-76.

4. Kronenberger T, Asse LR, Wrenger C, Trossini GHG, Honorio KM, Maltarollo VG. Studies of Staphylococcus aureus FabI inhibitors: Fragmentbased approach based on holographic structureactivity relationship analyses. Future Med Chem. 2017; 9(2): 135-51.

5. Yu JY, Cheng HJ, Wu HR, Wu WS, LuJW, Cheng TJ, Wu YT, Fang JM. Structure-based design of bacterial transglycosylase inhibitors incorporating biphenyl, amine linker and 2-alkoxy-3-phosphorylpropanoate moieties. Eur J Med Chem. 2018; 150:729-41.

6. Wu WS, Cheng WC, Cheng TJR, Wong CH. Affinity-Based Screen for Inhibitors of Bacterial Transglycosylase. J Am Chem Soc. 2018; 140(8): 2752-5.

7. Niu X, Gao Y, Yu Y, Yang Y, Wang G, Sun L, Wang $H$. Molecular Modelling reveals the inhibition mechanism and structure-activity relationship of curcumin and its analogues to Staphylococcal aureus Sortase A. J Biomol Struct Dyn. 2019; 37(5): 1220-30.

8. Chan AH, Yi SW, Weiner EM, Amer BR, Sue CK, Wereszczynski J, Dillen CA, Senese S, Torres JZ, McCammon JA, Miller LS, Jung ME, Clubb RT. NMR structure-based optimization of Staphylococ- cus aureus sortase A pyridazinone inhibitors. Chem Biol Drug Des. 2017; 90(3): 327-44.

9. He W, Zhang Y, Bao J, Deng X, Batara J, Casey $S$, Guo $Q$, Jiang $F, F u L$. Synthesis, biological evaluation and molecular docking analysis of 2-phenylbenzofuran-3-carboxamide derivatives as potential inhibitors of Staphylococcus aureus Sortase A. Bioorganic Med Chem. 2017; 25(4): 1341-51.

10. Zhang B, Wang X, Wang L, Chen S, Shi D, Wang H. Molecular mechanism of the flavonoid natural product dryocrassin ABBA against Staphylococcus aureus sortase A. Molecules. 2016; 21(11): pii: E1428.

11. Rentero Rebollo I, McCallin S, Bertoldo D, Entenza JM, Moreillon P, Heinis C. Development of Potent and Selective $\mathrm{S}$ aureus Sortase A Inhibitors Based on Peptide Macrocycles. ACS Med Chem Lett. 2016; 7(6): 606-11.

12. Maggio B, Raffa D, Raimondi MV, Cascioferro $S$, Plescia F, Schillaci D, Cusimano MG, Leonchiks A, Zhulenkovs D, Basile L, Daidone G. Discovery of a new class of sortase a transpeptidase inhibitors to tackle gram-positive pathogens: 2-(2-phenylhydrazinylidene)alkanoic acids and related derivatives. Molecules. 2016; 21(2): 241.

13. Gao C, Uzelac I, Gottfries J, Eriksson LA. Exploration of multiple Sortase A protein conformations in virtual screening. Sci Rep. 2016; 6: 204-213.

14. Ni S, Li B, Chen F, Wei H, Mao F, Liu Y, Xu Y, Qiu X, Li X, Liu W, Hu L, Ling D, Wang M, Zheng X, Zhu J, Lan L, Li J. Novel Staphyloxanthin Inhibitors with Improved Potency against Multidrug Resistant Staphylococcus aureus. ACS Med Chem Lett. 2018; 9(3): 233-7.

15. Wei H, Mao F, Ni S, Chen F, Li B, Qiu X, Hu L, Wang $M$, Zheng $X$, Zhu J, Lan L, Li J. Discovery of novel piperonyl derivatives as diapophytoene desaturase inhibitors for the treatment of methicillin-, vancomycin- and linezolid-resistant Staphylococcus aureus infections. Eur J Med Chem. 2018; 145:23551.

16. Wang Y, Di H, Chen F, Xu Y, Xiao Q, Wang X, Wei H, Lu Y, Zhang L, Zhu J, Lan L, Li J. Discovery of Benzocycloalkane Derivatives Efficiently Blocking Bacterial Virulence for the Treatment of MethicillinResistant S aureus (MRSA) Infections by Targeting 
Diapophytoene Desaturase (CrtN). J Med Chem. 2016; 59(10): 4831-48.

17. Chen F, Di H, Wang Y, Cao $Q$, Xu B, Zhang $X$, Yang $N$, Liu $G$, Yang $C G, X u$ Y, Jiang H, Lian F, Zhang $N$, Li J, Lan L. Small-molecule targeting of a diapophytoene desaturase inhibits $\mathrm{S}$ aureus virulence. Nat Chem Biol. 2016; 12(3): 174-9.

18. Bielenica A, Drzewiecka-Antonik A, Rejmak P, Stefańska J, Koliński M, Kmiecik S, Lesyng B, Włodarczyk M, Pietrzyk P, Struga M. Synthesis, structural and antimicrobial studies of type II topoisomerase-targeted copper(II) complexes of 1,3-disubstituted thiourea ligands. J Inorg Biochem. 2018; 182:61-70.

19. Alagumuthu M, Arumugam S. Molecular docking, discovery, synthesis, and pharmacological properties of new 6-substituted-2-(3-phenoxyphenyl)-4-phenyl quinoline derivatives; an approach to developing potent DNA gyrase inhibitors/antibacterial agents. Bioorganic Med Chem. 2017; 25(4): 1448-55.

20. Tan CM, Gill CJ, Wu J, Toussaint N, Yin J, Tsuchiya T, Garlisi CG, Kaelin D, Meinke PT, Miesel L, Olsen DB, Lagrutta A, Fukuda H, Kishii R, Takei M, Oohata K, Takeuchi T, Shibue T, Takano H, Nishimura A, Fukuda Y, Singh SB. In vitro and in vivo characterization of the novel oxabicyclooctanelinked bacterial topoisomerase inhibitor AM-8722, a selective, potent inhibitor of bacterial DNA gyrase. Antimicrob Agents Chemother. 2016; 60(8): 4830-9.

21. Zidar N, Tomašič T, Macut H, Sirc A, Brvar M, Montalvão S, Tammela P, Ilaš J, Kikelj D. New Nphenyl-4,5-dibromopyrrolamides and N-Phenylindolamides as ATPase inhibitors of DNA gyrase. Eur J Med Chem. 2016; 117:197-211.

22. Durcik M, Tammela P, Barančoková M, Tomašič T, Ilaš J, Kikelj D, Zidar N. Synthesis and Evaluation of N-Phenylpyrrolamides as DNA Gyrase B Inhibitors. ChemMedChem. 2018; 13(2): 186-98.

23. Mitton-Fry MJ, Brickner SJ, Hamel JC, Barham R, Brennan L, Casavant JM, Ding X, Finegan S, Hardink J, Hoang T, Huband MD, Maloney M, Marfat A, McCurdy SP, McLeod D, Subramanyam C, Plotkin M, Reilly U, Schafer J, Stone GG, Uccello DP, Wisialowski T, Yoon K, Zaniewski R, Zook C. Novel 3-fluoro-6-methoxyquinoline de- rivatives as inhibitors of bacterial DNA gyrase and topoisomerase IV. Bioorganic Med Chem Lett. 2017; 27(15): 3353-8.

24. Surivet JP, Zumbrunn C, Bruyère T, Bur D, Kohl C, Locher HH, Seiler P, Ertel EA, Hess P, EnderlinPaput M, Enderlin-Paput S, Gauvin JC, Mirre A, Hubschwerlen C, Ritz D, Rueedi G. Synthesis and Characterization of Tetrahydropyran-Based Bacterial Topoisomerase Inhibitors with Antibacterial Activity against Gram-Negative Bacteria. $J$ Med Chem. 2017; 60(9): 3776-94.

25. Jakopin Ž, Ilaš J, Barančoková M, Brvar M, Tammela P, Sollner Dolenc M, Tomašič T, Kikelj D. Discovery of substituted oxadiazoles as a novel scaffold for DNA gyrase inhibitors. Eur J Med Chem. 2017; 130:171-84.

26. Gjorgjieva M, Tomašič T, Barančokova M, Katsamakas S, Ilaš J, Tammela P, Mašič LP, Kikelj D. Discovery of Benzothiazole Scaffold-Based DNA Gyrase B Inhibitors. J Med Chem. 2016; 59(19): 8941-54.

27. Savage VJ, Charrier C, Salisbury AM, Moyo E, Forward H, Chaffer-Malam N, Metzger R, Huxley A, Kirk R, Uosis-Martin M, Noonan G, Mohmed S, Best SA, Ratcliffe AJ, Stokes NR. Biological profiling of novel tricyclic inhibitors of bacterial DNA gyrase and topoisomerase IV. J Antimicrob Chemother. 2016; 71(7): 1905-13.

28. Ballu S, Itteboina R, Sivan SK, Manga V. Structural insights of Staphylococcus aureus FtsZ inhibitors through molecular docking, 3D-QSAR and molecular dynamics simulations. J Recept Signal Transduct. 2018; 38(1): 61-70.

29. Bi F, Guo L, Wang Y, Venter H, Semple SJ, Liu F, $M a S$. Design, synthesis and biological activity evaluation of novel 2,6-difluorobenzamide derivatives through FtsZ inhibition. Bioorganic Med Chem Lett. 2017; 27(4): 958-62.

30. Qiang $S$, Wang $C$, Venter $H$, Li X, Wang Y, Guo L, $M a R, M a S$. Synthesis and Biological Evaluation of Novel FtsZ-targeted 3-arylalkoxy-2,6-difluorobenzamides as Potential Antimicrobial Agents. Chem Biol Drug Des. 2016; 87(2): 257-64.

31. Hrast M, Jukič M, Patin D, Tod J, Dowson CG, Roper DI, Barreteau H, Gobec S. In silico identifi- 
cation, synthesis and biological evaluation of novel tetrazole inhibitors of MurB. Chem Biol Drug Des. 2018; 91(6): 1101-12.

32. Vickery CR, Wood BMK, Morris HG, Losick R, Walker $S$. Reconstitution of Staphylococcus aureus Lipoteichoic Acid Synthase Activity Identifies Congo Red as a Selective Inhibitor. $J$ Am Chem Soc. 2018; 140(3): 876-9.

33. Paparella AS, Lee KJ, Hayes AJ, Feng J, Feng Z, Cini D, Deshmukh S, Booker GW, Wilce MCJ, Polyak SW, Abell AD. Halogenation of Biotin Protein Ligase Inhibitors Improves Whole Cell Activity against Staphylococcus aureus. ACS Infect Dis. 2018; 4(2): 175-84.

34. Feng J, Paparella AS, Booker GW, Polyak SW, Abell $A D$. Biotin protein ligase is a target for new antibacterials. Antibiotics. 2016; 5(3): pii: E26

35. Merzoug A, Chikhi A, Bensegueni A, Boucherit H, Okay S. Virtual Screening Approach of Bacterial Peptide Deformylase Inhibitors Results in New Antibiotics. Mol Inform. 2018; 37(3).

36. Schaenzer AJ, Wlodarchak N, Drewry DH, Zuercher WJ, Rose WE, Striker R, Sauer JD. A screen for kinase inhibitors identifies antimicrobial imidazopyridine aminofurazans as specific inhibitors of the Listeria monocytogenes PASTA kinase PrkA. $J$ Biol Chem. 2017; 292(41): 17037-45.

37. Wang B, Huang W, Zhou J, Tang X, Chen Y, Peng C, $H a n$. Drug design based on pentaerythritol tetranitrate reductase: Synthesis and antibacterial activity of Pogostone derivatives. Org Biomol Chem. 2017; 15(31): 6548-56.

38. Gao J, Qiu S, Liang L, Hao Z, Zhou Q, Wang F, Mou J, Lin $Q$. Design, Synthesis, and Biological Evaluation of Vanillin Hydroxamic Acid Derivatives as Novel Peptide Deformylase Inhibitors. Curr Comput Aided Drug Des. 2018; 14(1): 95-101.

39. Singh A, Srivastava R, Singh RK. Design, Synthesis, and Antibacterial Activities of Novel Heterocyclic Arylsulphonamide Derivatives. Interdiscip Sci Comput Life Sci. 2018; 10(4): 748-61.

40. Felicetti T, Cannalire R, Burali MS, Massari $S$, Manfroni G, Barreca ML, Tabarrini O, Schindler BD, Sabatini S, Kaatz GW, Cecchetti V. Searching for Novel Inhibitors of the S aureus NorA Efflux Pump:
Synthesis and Biological Evaluation of the 3-Phenyl-1,4-benzothiazine Analogues. ChemMedChem. 2017; 12(16): 1293-302.

41. Astolfi A, Felicetti T, Iraci N, Manfroni G, Massari S, Pietrella D, Tabarrini O, Kaatz GW, Barreca $M L$, Sabatini S, Cecchetti V. Pharmacophore-Based Repositioning of Approved Drugs as Novel Staphylococcus aureus NorA Efflux Pump Inhibitors. $J$ Med Chem. 2017; 60(4): 1598-604.

42. Buonerba F, Lepri S, Goracci L, Schindler BD, Seo SM, Kaatz GW, Cruciani G. Improved Potency of Indole-Based NorA Efflux Pump Inhibitors: From Serendipity toward Rational Design and Development. J Med Chem. 2017; 60(1): 517-23.

43. Bhaskar BV, Chandra Babu TM, Reddy NV, Rajendra $W$. Homology modeling, molecular dynamics, and virtual screening of nora efflux pump inhibitors of Staphylococcus aureus. Drug Des Devel Ther. 2016; 10:3237-52.

44. Costa LM, de Macedo E V., Oliveira FAA, Ferreira JHL, Gutierrez SJC, Peláez WJ, Lima FCA, de Siqueira Júnior JP, Coutinho HDM, Kaatz GW, de Freitas RM, Barreto HM. Inhibition of the NorA efflux pump of Staphylococcus aureus by synthetic riparins. J Appl Microbiol. 2016; 121(5): 1312-22.

45. Wani NA, Singh S, Farooq S, Shankar S, Koul S, Khan IA, Rai R. Amino acid amides of piperic acid (PA) and 4-ethylpiperic acid (EPA) as NorA efflux pump inhibitors of Staphylococcus aureus. Bioorganic Med Chem Lett. 2016; 26(17): 4174-8.

46. Liger F, Bouhours P, Ganem-Elbaz C, Jolivalt C, Pellet-Rostaing S, Popowycz F, Paris JM, Lemaire M. C2 Arylated Benzo[b]thiophene Derivatives as Staphylococcus aureus NorA Efflux Pump Inhibitors. ChemMedChem. 2016; 11(3): 320-30.

47. Gupta A, Mishra S, Singh S, Mishra S. Prevention of IcaA regulated poly $\mathrm{N}$-acetyl glucosamine formation in Staphylococcus aureus biofilm through newdrug like inhibitors: In silico approach and MD simulation study. Microb Pathog. 2017; 110:659-69.

48. El-Gazzar YI, Georgey HH, El-Messery SM, Ewida HA, Hassan GS, Raafat MM, Ewida MA, ElSubbagh HI. Synthesis, biological evaluation and molecular modeling study of new (1,2,4-triazole or 1,3,4-thiadiazole)-methylthio-derivatives of quinaz- 
olin-4(3H)-one as DHFR inhibitors. Bioorg Chem. 2017; 72: 282-92.

49. Elbaramawi SS, Ibrahim SM, Lashine ESM, ElSadek ME, Mantzourani E, Simons C. Exploring the binding sites of Staphylococcus aureus phenylalanine tRNA synthetase: A homology model approach. J Mol Graph Model. 2017; 73: 36-47.

50. Choi SR, Frandsen J, Narayanasamy P. Novel longchain compounds with both immunomodulatory and MenA inhibitory activities against Staphylococcus aureus and its biofilm. Sci Rep. 2017; 7: 40077.

51. Cui P, Li X, Zhu M, Wang B, Liu J, Chen H. Design, synthesis and antibacterial activities of thiouracil derivatives containing acyl thiourea as SecA inhibitors. Bioorganic Med Chem Lett. 2017; 27(10): 2234-7

.52. Feng J, Paparella AS, Tieu W, Heim D, Clark S, Hayes A, Booker GW, Polyak SW, Abell AD. New Series of BPL Inhibitors To Probe the RiboseBinding Pocket of Staphylococcus aureus Biotin Protein Ligase. ACS Med Chem Lett. 2016; 7(12): 1068-72.

53. Swarupa V, Chaudhury A, Krishna Sarma PVG. Effect of 4-methoxy 1-methyl 2-oxopyridine 3-carbamide on Staphylococcus aureus by inhibiting UDPMurNAc-pentapeptide, peptidyl deformylase and uridine monophosphate kinase. J Appl Microbiol. 2017; 122(3): 663-75.

54. North RA, Watson AJA, Pearce FG, Muscroft-Taylor AC, Friemann R, Fairbanks AJ, Dobson RCJ. Structure and inhibition of $\mathrm{N}$-acetylneuraminate lyase from methicillin-resistant Staphylococcus aureus. FEBS Lett. 2016; 590(23): 4414-28.

55. Marimuthu P, Singaravelu K, Namasivayam V. Probing the binding mechanism of mercaptoguanine derivatives as inhibitors of HPPK by docking and molecular dynamics simulations. J Biomol Struct Dyn. 2017; 35(16): 3507-21.

56. Dennis $M L$, Pitcher NP, Lee MD, Debono AJ, Wang ZC, Harjani JR, Rahmani R, Cleary B, Peat TS, Baell JB, Swarbrick JD. Structural Basis for the Selective Binding of Inhibitors to 6-Hydroxymethyl-7,8-dihydropterin Pyrophosphokinase from Staphylococcus aureus and Escherichia coli. J Med Chem. 2016; 59(11): 5248-63.
57. Ye F, Li J, Yang CG. The development of smallmolecule modulators for $\mathrm{ClpP}$ protease activity. $\mathrm{Mol}$ Biosyst. 2017; 13(1): 23-31.

58. Kakarla P, Floyd J, Mukherjee MM, Devireddy AR, Inupakutika MA, Ranweera I, Kc R, Shrestha $U$, Cheeti UR, Willmon TM, Adams J, Bruns M, Gunda SK, Varela MF. Inhibition of the multidrug efflux pump LmrS from Staphylococcus aureus by cumin spice Cuminum cyminum. Arch Microbiol. 2017; 199(3): 465-74.

59. Herman-Bausier P, Valotteau C, Pietrocola G, Rindi S, Alsteens D, Foster TJ, Speziale P, Dufrêne YF. Mechanical strength and inhibition of the Staphylococcus aureus collagen-binding protein Cna. MBio. 2016; 7(5): pii: e01529-16.

60. Hughes SJ, Barnard L, Mottaghi K, Tempel W, Antoshchenko T, Hong BS, Allali-Hassani A, Smil D, Vedadi $M$, Strauss E, Park $H W$. Discovery of potent pantothenamide inhibitors of staphylococcus Aureus Pantothenate Kinase through a minimal SAR Study: Inhibition Is Due to Trapping of the Product. ACS Infect Dis. 2016; 2(9): 627-41.

61. Wang Y, Desai J, Zhang Y, Malwal SR, Shin CJ, Feng $X$, Sun H, Liu G, Guo RT, Oldfield E. Bacterial Cell Growth Inhibitors Targeting Undecaprenyl Diphosphate Synthase and Undecaprenyl Diphosphate Phosphatase. ChemMedChem. 2016; 11(20): 2311-9.

62. Inokoshi J, Nakamura Y, Komada S, Komatsu K, Umeyama H, Tomoda H. Inhibition of bacterial undecaprenyl pyrophosphate synthase by small fungal molecules. J Antibiot (Tokyo). 2016; 69(11): 798-805.

63. Concha N, Huang J, Bai X, Benowitz A, Brady P, Grady LC, Kryn LH, Holmes D, Ingraham K, Jin $Q$, Pothier Kaushansky L, McCloskey L, Messer JA, O'Keefe H, Patel A, Satz AL, Sinnamon RH, Schneck J, Skinner SR, Summerfield J, Taylor A, Taylor JD, Evindar $G$, Stavenger RA. Discovery and Characterization of a Class of Pyrazole Inhibitors of Bacterial Undecaprenyl Pyrophosphate Synthase. J Med Chem. 2016; 59(15): 7299-304.

64. Zaveri K, Kiranmayi P. Screening of Potential Lead Molecule as Novel MurE Inhibitor: Virtual Screening, Molecular Dynamics and In Vitro Studies. Curr Comput Aided-Drug Des. 2016; 13(1): 8-21. 
65. Morvan C, Halpern D, Kénanian G, Hays C, AnbaMondoloni J, Brinster S, Kennedy S, Trieu-Cuot P, Poyart C, Lamberet G, Gloux K, Gruss A. Environmental fatty acids enable emergence of infectious Staphylococcus aureus resistant to FASII-targeted antimicrobials. Nat Commun. 2016; 7: 12944.

66. Labrière C, Gong $H$, Finlay BB, Reiner $N E$, Young $R N$. Further investigation of inhibitors of MRSA pyruvate kinase: Towards the conception of novel antimicrobial agents. Eur J Med Chem. 2017; 12: $51-13$.

67. El-Sayed MT, Zoraghi R, Reiner N, Suzen S, Ohlsen K, Lalk M, Altanlar N, Hilgeroth A. Novel inhibitors of the methicillin-resistant Staphylococcus aureus (MRSA)-pyruvate kinase. J Enzyme Inhib Med Chem. 2016; 31(6): 1666-71.

68. Holden JK, Lewis MC, Cinelli MA, Abdullatif Z, Pensa A V., Silverman RB, Poulos TL. Targeting Bacterial Nitric Oxide Synthase with Aminoquinoline-Based Inhibitors. Biochemistry. 2016; 55(39): 5587-94.

69. Zheng $W$, Cai X, Xie M, Liang Y, Wang T, Li Z. Structure-Based Identification of a Potent Inhibitor Targeting Stp1-Mediated Virulence Regulation in Staphylococcus aureus. Cell Chem Biol. 2016; 23(8): 1002-13.

70. Skupińska M, Stẹpniak P, Łẹtowska I, Rychlewski L, Barciszewska M, Barciszewski J, Giel-Pietraszuk M. Natural compounds as inhibitors of Tyrosyl-tRNA synthetase. Microb Drug Resist. 2017; 23(3): 308-20.

71. Desai J, Liu YL, Wei H, Liu W, Ko TP, Guo RT, Oldfield E. Structure, Function, and Inhibition of Staphylococcus aureus Heptaprenyl Diphosphate Synthase. ChemMedChem. 2016; 1915-23.

72. Bommineni GR, Kapilashrami K, Cummings JE, Lu Y, Knudson SE, Gu C, Walker SG, Slayden RA, Tonge PJ. Thiolactomycin-Based Inhibitors of Bacterial $\beta$-Ketoacyl-ACP Synthases with in Vivo Activity. J Med Chem. 2016; 59(11): 5377-90.

73. Czerwonka D, Domagalska J, Pyta K, Kubicka MM, Pecyna P, Gajecka M, Przybylski P. Structure-activity relationship studies of new rifamycins containing 1-amino acid esters as inhibitors of bacterial RNA polymerases. Eur J Med Chem. 2016; 116: 216-21.
74. Hou Y, Mayhood T, Sheth P, Tan CM, Labroli M, Su J, Wyss DF, Roemer T, McCoy MA. NMR Binding and Functional Assays for Detecting Inhibitors of S aureus MnaA. J Biomol Screen. 2016; 21(6): 579-89.

75. Joung DK, Lee YS, Han SH, Lee SW, Cha SW, Mun SH, Kong R, Kang OH, Song HJ, Shin DW, Kwon DY. Potentiating activity of luteolin on membrane permeabilizing agent and ATPase inhibitor against methicillin-resistant Staphylococcus aureus. Asian Pac J Trop Med. 2016; 9(1): 19-22.

76. Addo JK, Skaff DA, Miziorko HM. Active site binding modes of inhibitors of Staphylococcus aureus mevalonate diphosphate decarboxylase from docking and molecular dynamics simulations. $J \mathrm{Mol}$ Model. 2016; 22(1): 1-18.

77. Mesleh MF, Rajaratnam P, Conrad M, Chandrasekaran V, Liu CM, Pandya BA, Hwang YS, Rye PT, Muldoon C, Becker B, Zuegg J, Meutermans W, Moy TI. Targeting Bacterial Cell Wall Peptidoglycan Synthesis by Inhibition of Glycosyltransferase Activity. Chem Biol Drug Des. 2016; 87(2): 190-9.

78. Vuong C, Yeh AJ, Cheung GYC, Otto M. Investigational drugs to treat methicillin-resistant Staphylococcus aureus. Expert Opin Investig Drugs. 2016; 25(1): 73-93.

79. Yadav PK, Singh G, Singh S, Gautam B, Saad EI. Potential therapeutic drug target identification in Community Acquired-Methicillin Resistant Staphylococcus aureus (CA-MRSA) using computational analysis. Bioinformation. 2012; 8(14): 664-72.

80. Hossain M, Chowdhury DUS, Farhana J, Akbar MT, Chakraborty A, Islam S, Mannan A. Identification of potential targets in Staphylococcus aureus N315 using computer aided protein data analysis. Bioinformation. 2013; 9(4): 187-92.

81. Uddin R, Saeed K. Identification and characterization of potential drug targets by subtractive genome analyses of methicillin resistant Staphylococcus aureus. Comput Biol Chem. 2014; 48: 55-63.

82. Uddin R, Saeed K, Khan W, Azam SS, Wadood A. Metabolic pathway analysis approach: Identification of novel therapeutic target against methicillin resistant Staphylococcus aureus. Gene. 2015; 556(2): 213-26. 
83. Hasan MA, Khan MA, Sharmin T, Hasan Mazumder $M H$, Chowdhury AS. Identification of putative drug targets in Vancomycin-resistant Staphylococcus aureus (VRSA) using computer aided protein data analysis. Gene. 2016; 575(1): 132-43.84. Zhang $R$. DEG: a database of essential genes. Nucleic Acids Res. 2004; 32(90001): 271D - 272.

85. Luo H, Lin Y, Gao F, Zhang CT, Zhang R. DEG 10, an update of the database of essential genes that includes both protein-coding genes and noncoding genomic elements. Nucleic Acids Res. 2014; 42(D1): 574-580.

86. Kanehisa M, Goto S. Yeast Biochemical Pathways KEGG: Kyoto encyclopedia of genes and genomes. Nucleic Acids Res. 2000; 28(1): 27-30.

87. Kanehisa M, Furumichi M, Tanabe M, Sato Y, Morishima K. KEGG: New perspectives on genomes, pathways, diseases and drugs. Nucleic Acids Res. 2017; 45(D1): D353-61.

88. Moriya Y, Itoh M, Okuda S, Yoshizawa AC, Kanehisa $M$. KAAS: An automatic genome annotation and pathway reconstruction server. Nucleic Acids Res. 2007; 35(SUPPL.2): 182-185.

89. Wishart DS, Feunang YD, Guo AC, Lo EJ, Marcu A, Grant JR, Sajed T, Johnson D, Li C, Sayeeda Z, Assempour N, Iynkkaran I, Liu Y, MacIejewski A, Gale N, Wilson A, Chin L, Cummings R, Le Di, Pon A, Knox C, Wilson M. DrugBank 50: A major update to the DrugBank database for 2018. Nucleic Acids Res. 2018; 46(D1): D1074-82.

90. Gardy JL, Brinkman FSL. Methods for predicting bacterial protein subcellular localization. Nat Rev Microbiol. 2006; 4(10): 741-51.

91. Yu CS, Chen YC, Hwang JK. Prediction of protein subcellular localization. Proteins. 2006; 64(3): 643651.

92. Wu Z-C, Xiao X, Chou K-C. iLoc-Gpos: A MultiLayer Classifier for Predicting the Subcellular Localization of Singleplex and Multiplex Gram-Positive Bacterial Proteins. Protein Pept Lett. 2012; 19(1): 4-14.

93. Bagos PG, Tsirigos KD, Liakopoulos TD, Hamodrakas $S J$. Prediction of lipoprotein signal peptides in Gram-positive bacteria with a Hidden Markov Model. J Proteome Res. 2008; 7(12): 5082-93.
94. Swiss-Model web-server https://swissmodel.expasy. org/interactive. Accessed 1 November 2019.

95. Waterhouse A, Bertoni M, Bienert S, Studer G, Tauriello G, Gumienny R, Heer FT, De Beer TAP, Rempfer C, Bordoli L, Lepore R, Schwede T. SWISSMODEL: Homology modelling of protein structures and complexes. Nucleic Acids Res. 2018; 46(W1): W296-303.

96. Guex N, Peitsch MC, Schwede T. Automated comparative protein structure modeling with SWISSMODEL and Swiss-PdbViewer: A historical perspective. Electrophoresis. 2009; 30: S162-S173.

97. Bienert $S$, Waterhouse A, de Beer TAP, Tauriello G, Studer G, Bordoli L, Schwede T. The SWISS-MODEL Repository - new features and functionality. Nucleic Acids Res. 2017; 45: D313-D319.

98. Benkert P, Biasini M, Schwede T. Toward the estimation of the absolute quality of individual protein structure models. Bioinformatics. 2011; 27: $343-$ 350.

99. Bertoni M, Kiefer F, Biasini M, Bordoli L, Schwede T. Modeling protein quaternary structure of homo- and hetero-oligomers beyond binary interactions by homology. Sci Rep. 2017; 7: 10480.

100. Phyre2 web-server http://www.sbg.bio.ic.ac.uk/ phyre $2 / \mathrm{html} /$ page.cgi?id=index. Accessed 1 November 2019.

101. Kelley LA, Mezulis S, Yates CM, Wass MN, Sternberg $M J$. The Phyre2 web portal for protein modeling, prediction and analysis. Nat Protoc. 2015; 10(6): 845-858.

102. I-TASSER web server https://zhanglab.ccmb.med. umich.edu/I-TASSER/. Accessed 1 November 2019.

103. Roy A, Kucukural A, Zhang Y. I-TASSER: a unified platform for automated protein structure and function prediction. Nat Protoc. 2010; 5: 725-738.

104. Yang J, Yan R, Roy A, Xu D, Poisson J, Zhang Y. The I-TASSER Suite: protein structure and function prediction. Nat. Methods. 2015; 12: 7-8.

105. Yang J, Zhang Y. I-TASSER server: new development for protein structure and function predictions. Nucleic Acids Res. 2015; 43: W174-W181.

106. Webb B, Sali A. Comparative protein structure modeling using MODELLER. Curr Protoc Bioinformatics. 2016; 56: 5.6.1-5.6.37. 
107. Marti-Renom MA, Stuart A, Fiser A, Sanchez R, Melo $F$, Sali $A$. Comparative protein structure modeling of genes and genomes. Annu Rev Biophys Biomol Struct. 2000; 29: 291-325.

108. Sali A, Blundell TL. Comparative protein modelling by satisfaction of spatial restraints. J Mol Biol. 1993; 234: 779-815.

109. Fiser A, Do RK, Sali A. Modeling of loops in protein structures. Protein Sci. 2000; 9: 1753-1773.

110. Hess B, Kutzner C, van der Spoel D, Lindahl E. GROMACS 4: Algorithms for highly efficient, loadbalanced, and scalable molecular simulation. J Chem Theory Comput. 2008; 4: 435-447.

111. Van der Spoel D, Lindahl E, Hess B, Groenhof $G$, Mark AE, Berendsen HJC. GROMACS: Fast, Flexible and Free. J Comp Chem. 2005; 26: 1701-1719.

112. Berendsen HJC, van der Spoel D, van Drunen $R$. GROMACS: A message-passing parallel molecular dynamics implementation. Comp Phys Comm. 1995; 91: 43-56.

113. Chen VB, Arendall WB, Headd JJ, Keedy DA, Immormino RM, Kapral GJ, Murray LW, Richardson JS, Richardson DC. MolProbity: All-atom structure validation for macromolecular crystallography. Acta Crystallogr Sect D Biol Crystallogr. 2010; 66(1): 12-21.

114. Konc J, Janežič D. ProBiS tools (algorithm, database, and web servers) for predicting and modeling of biologically interesting proteins. Prog Biophys Mol Biol. 2017; 128: 24-32.

115. Daum LT, Bumah V V., Masson-Meyers DS, Khubbar M, Rodriguez JD, Fischer GW, Enwemeka CS, Gradus S, Bhattacharyya S. Whole-genome sequence for methicillin-resistant Staphylococcus aureus strain ATCC BAA-1680. Genome Announc. 2016; 3(2): e00011-15.

116. Sabirova JS, Xavier BB, Hernalsteens JP, De Greve H, Ieven M, Goossens H, Malhotra-Kumar S. Complete genome sequences of two prolific biofilmforming Staphylococcus aureus isolates belonging to USA300 and EMRSA-15 clonal lineages. Genome Announc. 2014; 2(3): e00610-14.

117. Golding GR, Bryden L, Levett PN, Mcdonald RR, Wong A, Graham MR, Tyler $S$, van Domselaar $G$, Mabon P, Kent H, Butaye P, Smith TC, Kadlec K,
Schwarz S, Weese SJ, Mulvey MR. Whole-genome sequence of livestock-associated ST398 methicillin-resistant Staphylococcus aureus isolated from humans in Canada. J Bacteriol. 2012; 194(23): 6627-8.

118. Holden MTG, Feil EJ, Lindsay JA, Peacock SJ, Day NPJ, Enright MC, Foster TJ, Moore CE, Hurst L, Atkin R, Barron A, Bason N, Bentley SD, Chillingworth $C$, Chillingworth T, Churcher $C$, Clark L, Corton C, Cronin A, Doggett J, Dowd L, Feltwell T, Hance Z, Harris B, Hauser H, Holroyd $S$, Jagels $K$, James KD, Lennard $N$, Line A, Mayes $R$, Moule S, Mungall K, Ormond D, Quail MA, Rabbinowitsch E, Rutherford K, Sanders M, Sharp $S$, Simmonds M, Stevens K, Whitehead S, Barrell BG, Spratt BG, Parkhill J. Complete genomes of two clinical Staphylococcus aureus strains: Evidence for the evolution of virulence and drug resistance. Proc Natl Acad Sci U S A. 2004; 101(26): 9786-91.

119. Steinig EJ, Andersson P, Harris SR, Sarovich DS, Manoharan A, Coupland P, Holden MTG, Parkhill J, Bentley SD, Robinson DA, Tong SYC. Singlemolecule sequencing reveals the molecular basis of multidrug-resistance in ST772 methicillin-resistant Staphylococcus aureus. BMC Genomics. 2015; 16(1): 388.

120. Gaviria-Agudelo C, Aroh C, Tareen N, Wakeland EK, Kim M, Copley LA. Genomic heterogeneity of Methicillin resistant Staphylococcus aureus associated with variation in severity of illness among children with acute hematogenous osteomyelitis. PLoS One. 2015; 10(6): e0130415.

121. Hediger MA, Turk E, Wright EM. Homology of the human intestinal $\mathrm{Na}+/$ glucose and Escherichia coli $\mathrm{Na}+$ /proline cotransporters. Proc Natl Acad Sci U S A. 1989; 86(15): 5748-52.

122. Swango KL, Hymes J, Brown P, Wolf B. Amino acid homologies between human biotinidase and bacterial aliphatic amidases: Putative identification of the active site of biotinidase. Mol Genet Metab. 2000; 69(2): 111-115.

123. Chen IT, Dixit A, Rhoads DD, Roufa DJ. Homologous ribosomal proteins in bacteria, yeast, and humans. Proc Natl Acad Sci U S A. 1986; 83(18): 6907-11. 
124. Willers J, Lucchese A, Kanduc D, Ferrone S. Molecular mimicry of phage displayed peptides mimicking GD3 ganglioside. Peptides. 1999; 20(9): 1021-6.

125. Natale C, Giannini T, Lucchese A, Kanduc D. Computer-assisted analysis of molecular mimicry between human papillomavirus 16 E7 oncoprotein and human protein sequences. Immunol Cell Biol. 2000; 78(6): 580-5.

126. Opoku-Temeng C, Sintim HO. Inhibition of cyclic diadenylate cyclase, DisA, by polyphenols. Sci Rep. 2016; 6: 25445.

127. Opoku-Temeng C, Sintim HO. Potent inhibition of cyclic diadenylate monophosphate cyclase by the antiparasitic drug, suramin. Chem Commun. 2016; 52(19): 3754-7.

128. Pasquina L, Santa Maria JP, McKay Wood B, Moussa SH, Matano LM, Santiago M, Martin SES, Lee W, Meredith TC, Walker S. A synthetic lethal approach for compound and target identification in Staphylococcus aureus. Nat Chem Biol. 2016; 12(1): 40-5.

129. Rosenberg J, Dickmanns A, Neumann P, Gunka K, Arens J, Kaever V, Stülke J, Ficner R, Commichau FM. Structural and biochemical analysis of the essential diadenylate cyclase CdaA from Listeria monocytogenes. J Biol Chem. 2015; 290(10): 6596606.

\section{Пошук нових молекулярних мішеней, асоційованих $з$ мембраною, для розробки антибіотиків проти метицилін-резистентного штаму Staphylococcus aureus in silico}

А. Ю. Пернатій, Г. П. Волинець, М. В. Протопопов, В. М. Сапелкін, Л. В. Плетньова, В. І. Матюшок, В. Г. Бджола, С.М. Ярмолюк.

Мета. Метою дослідження був пошук нових мішеней для дизайну антибіотиків проти метицилін-резистентного штаму $S$. aureus (MRSA) методами розрахункової протеоміки. Методи. Ідентифікація негомологічних білків до людського протеому, визначення генів важливих для виживання MRSA та встановлення новизни знайдених мішеней проводили алгоритмами BLAST. За допомогою утиліт бази даних KEGG ідентифікува- ли унікальні метаболічні шляхи бактерій. Клітинну локалізацію протеїнів передбачали програмами PSORT v. 3.0.2, CELLO v. 2.5, iLoc-Gpos, та Pred-Lipo. Гомологічне моделювання проводили веб-серверами SWISS-MODEL, Phyre2, I-TASSER та MODELLER. Результати. Початкову вибірку було сформовано 3 протеомів шести штамів MRSA: ATCC BAA-1680, H-EMRSA-15, LA MRSA ST398, MRSA 252, MRSA ST772, UTSW MRSA 55. Багатостадійний аналіз вибраних протеомів за допомогою алгоритму BLAST дозволив ідентифікувати дві потенційні молекулярні мішені - диаденілатциклазу та білок DltB, що відповідають заданим вимогам: $є$ важливими для виживання бактерії, є асоційованими з мембранами, не є гомологами людських білків, залучені до унікальних метаболічних шляхів та раніше не досліджувались як терапевтична мішень. Було побудовано просторові структури знайдених протеїнів. Висновки. У результаті дослідження методами лінійної біоінформатики запропоновано дві потенційні мішені - диаденілатциклазу та білок DltB, для подальшої розробки антибіотиків проти метицилін-резистентного штаму бактерії Staphylococcus aureus методами раціонального пошуку лікарських засобів.

Кл юч о в і сл о в а: MRSA, MDR-PA, порівняльна протеоміка, гомологічне моделювання, молекулярні мішені.

\section{Поиск новых мембраносвязанных молекулярных мишеней для разработки антибиотиков против метициллин- резистентного штамма Staphylococcus aureus in silico}

А. Ю. Пернатий, Г. П. Волинец, М. В. Протопопов, В. М. Сапелкин, Л. В. Плетнёва, В. И. Матюшок, В. Г. Бджола, С. Н. Ярмолюк.

Цель. Определить новые мишени для дизайна антибиотиков против метицил-лин-резистентного штамма S. aureus (MRSA) методами расчетной протеомики. Методы. Идентификация негомологичных последовательностей с человеческими, определение критических для выживания MRSA белков и определение их новизны как терапевтических мишеней проводилось алгоритмами BLAST. При помощи утилит базы дан- 
ных KEGG идентифицировали уникальные метаболические пути бактерии. Клеточную локализацию определяли программным обеспечением PSORT v. 3.0.2, CELLO v. 2.5, iLoc-Gpos и Pred-Lipo. Гоммологическое модели были построены веб-серверами SWISSMODEL, Phyre2, I-TASSER и программой MODELLER. Результаты. Первоначальная выборка была составлена с протеомов шести штаммов MRSA: ATCC BAA1680, H-EMRSA-15, LA MRSA ST398, MRSA 252, MRSA ST772, UTSW MRSA 55. Многостадийный анализ отобранных протеомов алгоритмом BLAST позволил идентифицировать две потенциальные молекулярные мишени: диаденилатциклазу и белок DltB, соответствующие критериям критичности для выживания, которые не гомологичны к человеческим бел- кам, ранее не исследовались при разработке антибиотических средств и локализованы в мембране. Также была построена трёхмерная модель найденных мишеней. Выводы. В ходе исследования, методами линейной биоинформатики было определено два белка-мишени - диаденилатциклаза и белок DltB, для последующей разработки антибиотических препаратов против метициллин-резистентного штамма Staphylococcus aureus методами рационального поиска лекарственных средств.

Кл юч е в ы е с л о в а: MRSA, MDR-PA, сравнительная протеомика, гомологическое моделирование, молекулярные мишени.

Received 02.10.2019 